УДК94.001.73 (47+57) «1865/1919»

https://doi.org/10.34142/2313-2345.2019.56.11

Пересада О. С.

аспірант кафедри всесвітньої історіі Харківського національного педагогічного університету імені Г.С. Сковороди

\title{
ШКІЛЬНА ДІЯЛЬНІСТЬ ЗЕМСЬКОГО САМОВРЯДУВАННЯ НА ХАРКІВЩИНІ У 1865-1919 РОКАХ
}

У статті досліджується процес становлення та розвитку земських шкіл на території Харківської губерніїу 1865-1919 роках. Аналізуються масштаби та динаміка розвитку народної освіти на Харківщині, досягнення та недоліки шкільної діяльності харківського земства, а також ефективність діяльності земства в справі забезпечення початкових народних икіл вчительськими кадрами. В роботі проаналізовані основні фактори розвитку народної освіти, щуо виявилися в українському суспільстві; установлені соціальні механізми реалізації освітніх потреб, пов 'язані з діяльністю земських органів самоврядування; вивчений характер, організаційні форми, методи й прийоми, якими керувалися земські органи самоврядування для досягнення цілі забезпечення народних шкіл вчительськими кадрами, поширення серед сільського населення книжкової культури й корисних знань. Автором роботи робиться спроба здійснити новий підхід до вивчення обраної проблеми, запропоновано власний варіант розуміння місия і ролі земства в розвитку народної освіти, виділені суттєві риси розвитку украӥнських земськихшкіл, найбільш важливі з точки зору врахування можливостей їх використання на користь сучасних навчальних закладів. В статті доведено, щуо саме земська діяльність забезпечила кількісне і якісне зрушення української шкільної системи, суспільне розуміння освіти як фундаментального права людини й найважливішої умови поліпшення якості жсття; установлено, щзо в розглянутих історичних умовах найбільш значні новації в украйнській системі освіти були ініційовані земськими органами в співробітництві з педагогічною громадськістю; зроблено внесок в справу відродження та популяризації забутих імен видатних земських вчителів, які працювали в школах Харківської губернї.

Ключові слова: земські установи, народна освіта, харківське земство, земська школа, реалізація освітніх потреб, земські вчителі, історико-педагогічний досвід.

The article examines the process of formation and development of land schools in the Kharkiv province in 1865-1919. The scales and dynamics of development of public education in Kharkiv region, achievements and shortcomings of school activity of Kharkiv zemstvo, and also efficiency of activity of 
zemstvo in providing primary public schools with teachers are analyzed. The author of the article defines a new productive direction analysis of regional pedagogical experience as the basis of national achievements in the field of education. The main attention is paid to the study of the role of local governments of the Kharkiv province in the progressive development of public education in Ukraine. The main factors of development of public education, which appeared in the Ukrainian society, are analyzed in the work; established social mechanisms for the implementation of educational needs related to the activities of zemstvos; studied the nature, organizational forms, methods and techniques used by zemstvos to achieve the goal of providing public schools with teachers, dissemination of book culture and useful knowledge among the rural population. The author attempts to implement a new approach to studying the chosen problem, proposed his own understanding place and role of the zemstvo in the development of public education, highlighted the essential features of the development of Ukrainian zemstvoschools, the most important in terms of taking into account the possibilities of their use in favor of modern schools. The article proves that zemstvo activity has provided quantitative and qualitative shift education as a fundamental human right and the most important condition for improving the quality of life; it is established that in the considered historical conditions the most significant innovations in the Ukrainian education system were initiated by zemstvo bodies in cooperation with the pedagogical community; a contribution was made to the revival and popularization of the forgotten names of prominent Zemstvo teachers who worked in schools of the Kharkiv province.

Key words: zemstvo institutions, public education, Kharkiv zemstvo, zemstvo school, realization of educational needs, zemstvo teachers, historical and pedagogical experience.

Постановка проблеми. Земства, які були створені в українських губерніях в 1860-1870-х роках XIX ст., стали важливою складовою частиною українського суспільства і суттєво вплинули на динаміку його модернізації. Поява земства у Харківській губернії сприяла вирішенню значного кола освітніх та інших гуманітарних проблем, що гальмували розвиток регіону. Забезпечення земством початкової народної школи вчительськими кадрами в кількісному і якісному відношенні представляло одну з важливих і важких сторін шкільної справи. Земський вчитель став засновником і творцем земської школи на якому грунтувалися iii успіхи. Актуальність наукового дослідження діяльності харківського земства в галузі народної освіти у 1865-1919 роках зумовлена потребою наукового осмислення ролі земств у розвитку Харківської губернії у період модернізації України відносин; важливістю вивчення механізму діяльності земств у ході вирішення місцевих соціальних та культурних потреб; необхідністю пізнання загальних закономірностей діяльності органів місцевого самоврядування у переломний період історії України з урахуванням особливостей національного розвитку. Отже, дослідження основних напрямів діяльність повітових і губернського земств Харківської губернії в галузі народної освіти у 1864-1919 роках дозволяє ширше висвітлити та вирішити низку питань, пов'я- заних з історією України, що мають як наукове, так і громадське значення.

Аналіз актуальних досліджень. Основні напрями гуманітарної діяльності Харківського земства в галузі народної освіти широко відображалися в історичній літературі. Суттєвіший внесок у наукову розробку цього питання зробили такі дослідники: Б. Б. Веселовский, Р. Л. Гавриш, А. М. Гуз, Л. М. Дровозюк, Е. А. Звягинцев, Л. В. Корж, В. В. Курченко, О. І. Мармазова, А. С. Пругавин, М. В.Чехов та ін. Роботи цих авторів вирізняються насиченістю фактичним матеріалом і новизною постановки проблеми. Проте спеціальної праці, яка б охоплювала історію розвитку органів земського самоврядування та Харківщині та весь комплекс його діяльності в галузі народної освіти, ні в українській, ні в зарубіжній історіографії немає.

Таким чином, зроблений вище аналіз історіографії теми дослідження дозволяє 3 достатньою підставою стверджувати, що в історичній літературі створені серйозні передумови і достатня опорна база для подальшого грунтовного вивчення історії шкільної діяльності земського самоврядування на Харківщині у 1865-1919 роках. Ця обставина стала однією із головних причин вибору автором теми для свого дослідження, а також визначила мету, основні завдання та дослідницькі параметри. 
Мета статті полягає у комплексному дослідженні діяльності повітових та губернського земств Харківської губернії як органів місцевого самоврядування, спрямованої на розвиток народної освіти та вирішення проблеми забезпечення початкових народних шкіл вчительськими кадрами в кількісному і якісному відношенні, що представляло одну з важливих і важких сторін шкільної справи. Для досягнення мети автор поставив такі наукові завдання дослідження: обгрунтувати існування на Харківщині передумов і умов широкого розвитку діяльності місцевого самоврядування в галузі народної освіти; проаналізувати зміст політики царського уряду відносно освітньої діяльності земських органів та іiі здійснення на Харківщині; охарактеризувати основні напрями діяльності харківського земства в сфері народної освіти; простежити напрацювання земських органів щодо забезпечення земських шкіл вчительськими кадрами; проаналізувати наслідки освітньої діяльності земських установ у Харківській губернії. Обрані мета і завдання дослідження цілком відповідають вимогам сучасної історичної науки щодо кардинального оновлення й поглиблення розробки регіональної історії українських земств, а також відповідає сучасним державним планам і програмам по вдосконаленню в Україні системи місцевого самоврядування.

Наукова новизна та теоретичне значення представленої статті полягає в тому, що у процесі дослідження автором було сформульоване й вирішеневажливе наукове завдання - осмислена й оцінена роль органів місцевого самоврядування Харківської губернії у поступальному розвитку системи народної освіти в Україні протягом другої половині XIX - початку XX ст. Автором проаналізовані основні фактори розвитку народної освіти, що виявилися в українському суспільстві у зв'язку з його трансформацією й модернізацією на основі цінностей ринкової економіки та процесу українського державотворення; установлені соціальні механізми реалізації освітніх потреб, пов'язані з діяльністю земських органів самоврядування, простежений органічний зв'язок успіхів у розвитку народного освіти із принципами місцевого самовряду- вання; вивчений характер, організаційні форми, методи й прийоми, якими керувалися земські органи самоврядування для досягнення цілі забезпечення народних шкіл вчительськими кадрами; доведено, що саме земська діяльність забезпечила кількісне і якісне зрушення української шкільної системи, суспільне розуміння освіти як фундаментального права людини й найважливішої умови поліпшення якості життя; установлено, що в розглянутих історичних умовах найбільш значні новації в українській системі освіти були ініційовані земськими органами в співробітництві 3 педагогічною громадськістю; зроблено внесок в справу відродження та популяризації забутих імен видатних земських вчителів, які працювали в школах Харківської губернії. До новизни роботи також цілком можна віднести широке використання в ній i включення в науковий обіг цілої групи маловідомих раніше конкретно-фактичних матеріалів, що розкривають багатогранну діяльність земського самоврядування Харківської губернії по мобілізації внутрішніх ресурсів для розвитку шкільної освіти й просвітительської справи.

Виклад основного матеріалу. В пореформеній Харківській губернії одним 3 головних напрямків гуманітарної діяльності Харківського земства був розвиток народної освіти. В основу земської освітньої діяльності було покладено той принцип, за яким земствам рекомендувалося дотримуватися заохочувальної системи, надавати сільським громадам певну допомогу, головні ж витрати повинні нести самі селяни, щоб вони могли ставати самостійними і вирішувати, на що витрачати свої кошти. Саме тому на початку свого існування Харківське земство витрачало на школи відносно мало коштів [Чарнолуский 1911: 87-116]. В земських колах існувала думка, що сільська школа - це далеко не головна земська справа і максимум того, що можна робити для шкіл, - це надавати їм посильну матеріальну допомогу. Подібно до того, як уряд не вважав своїм обов'язком утримання початкових шкіл, так і земства вважали, що відкриття шкіл і турбота про них $є$ прямим обов'язком сільських громад.Таке відношення до народної освіти відповідало духу 
i букві закону про земські заклади, в яких говорилося лише про «участь переважно в господарському відношенні в опіці про народну освіту» [Вологдин 1914: 410-411]. В 1870-ті роки «необов'язкова» народна освіта поступово виходить за своїм значення за межі законодавчо окресленої компетенції земств, поголовна неписьменність населення Харківської губернії стала серйозним гальмом розвитку тут ринкових відношень, $\mathrm{i}$ тому земство суттєво змінило своє відношення до народної освіти. Спочатку земства відкривали школи лише в окремих слободах і селах до того при умові, що сільські громади брали на себе частину видатків на ïх утримання. 3 часом все частіше виникали і чисто земські школи, з цього моменту початкова школа припиняла існування при церкві, волосному правлінні або поміщицькій конторі, як це було в дореформений період. Школа перетворилася на самостійний заклад, який фінансувався земствами [Гордеенко 1885:34-36].

Реорганізацію старої школи Харківське земство почало з формування педагогічного персоналу. Кінець 1860-х - початок 1870-х рр. стали часом відновлення народної школи, впровадження нових методів навчання дітей, підготовки педагогічних кадрів [Соколов 1912: 838-843]. Для підвищення якісного складу вчителів шкіл земство намагалося використовувати можливості учительських з’їздів та різних педагогічних курсів, на яких вчителі обмінювались досвідом роботи, засвоювали більш раціональні методи та засоби навчання, давали пробні уроки. 3 перших кроків своєї діяльності земські органи самоврядування взяли курс на формування вчительських кадрів переважно із числа представників сільської молоді. Тільки таким чином, на думку земців, можна було гарантувати стабільність кадрового складу сільської школи, створити в українському селі особливий шар «культурних працівників»[Земская школа и педагогика 1997: 174179].В 1872 році в м. Вовчанську на земські кошти була відкрита чоловіча вчительська семінарія, яка до початку XX ст. залишалась основним учбовим закладом губернії 3 підготовки земських вчителів. Уже перший набір першої на Слобідській Україні земсь- кої вчительської семінарії більш ніж наполовину складався із селянських юнаків. Доповідаючи керівництву про діяльність вчительської семінарії за перший рік роботи, іiі адміністрація підкреслювала особливі успіхи семінаристів із селян, які проявляли себе у всьому із самої кращої сторони [Веселовский 1914: 393-395].

Із появою і зростанням земської школи було пов'язане формування найбільш численного загону земської інтелігенції учителів [Ежегодник МВД 1913:300-312]. Діяльність учителя народної школи була багатогранна, від нього залежали якість і глибина навчання дітей, на нього були покладені обов'язки завідувати народною бібліотекою, керувати читанням читачів, рекомендувати ті або інші книги. Земський учитель став одним 3 організаторів й учасників проведення народних читань, додаткових класних занять й, нарешті, одним із головних учасників освітніх починань.

У Харківській губернії земство прагнуло закріпити пріоритетне право навчання в педагогічних навчальних закладах за представниками селянського стану. При цьому земство не тільки відкривало можливості селянським дітям для навчання у власних навчальних закладах, але й субсидіювали навчання вихідців із селянства в міністерських учительських інститутах i семінаріях [Соколов 1912: 838-843]. Свою позицію в даному питанні Харківському земству доводилося відстоювати в гострій полеміці з тими, хто думав, що єдино прийнятною фігурою для навчання селянських дітей $є$ сільський священник, а також із тими, хто вважав кращими вчителями народної школи відставних армійських унтерофіцерів. Подібні судження висловлювалися переважно урядовими чиновниками та представниками духівництва [Веселовский 1909: 447-592].

Харківському земству належала важлива роль у боротьбі за 3 матеріального становища й соціального статусу народних учителів. У Харківській губернії земство постійно прагнуло до підвищення престижу вчительської професії. Включившись у роботу по розвитку народної освіти в середині 1890-х pр., губернське земство звернули на оплату праці вчителів особливу увагу й 
разом 3 повітовими земськими органами почало брати участь у іï фінансуванні [Материалы к вопросу об участии 1916: 126148]. Поступово в Харківській губернії почала затверджуватися практика прогресивної оплати праці вчителів. Через кожні п'ять років роботи вчителям земських школа стали робитися надбавки до основного окладу. Постійно вдосконалювалися система пенсійного забезпечення земських педагогічних кадрів, а також організація вчительської взаємодопомоги [Земство и народное образование 1909: 17]

Завдяки діяльності земських установмережа початкових шкіл в Харківській губернії поступово розширювалась. До 1913 р. тут нараховувалося вже 2158 шкіл, в тому числі 1095 земських [Земско-школьная деятельность 1912: 129-282]. В перші десятиріччя ХХст. Харківське земство значно розширило свою роботу в галузі народної освіти і медицини. Видатки на школи в ці роки порівняно з попереднім періодом збільшилися щорічно на 8-10\% і досягли в 1915 p. 144 тис. крб. В загальному бюджеті земства це вже становило близько $27 \%$ [Отчет об устройстве 1912: 169]. Поряд із таким загальним зростанням динаміки діяльності Харківського земства в справі розвитку народної освіти суттєво змінились і їі пріоритети [Абрамов 1998: 48-50]. Якщо в 1860-90-ті роки основні зусилля земства були спрямовані на створення лише народних шкіл, то в перше десятиріччя XX ст. земство вважало своїм основним завданням активну участь в підготовці педагогічних кадрів і в створенні для цієї мети загальногубернської системи педагогічної освіти, без вирішення цього завдання був неможливий подальший поступовий розвиток всієї системи освіти на Харківщині. При цьому 3 особливою гостротою стало питання, перш за все, про підготовку викладачів для початкової народної школи, перед якою в цей час вперше відкривалася реальна перспектива охопити початковою освітою все населення губернії [Корф 1867: 34-38].

Забезпечення початкової народної школи вчительським персоналом у кількісному і якісному відношенні було одним із важливих і важких завдань шкільної справи. Земський учитель начальної народної школи став і засновником iї, i творцем, i центром, на якому головним чином базувалися успіхи школи. Усе залежало від його підготовленості до вчительської діяльності, від його освіти, загального розвитку, від його відношення до даної справи й взагалі від його особистих якостей. Учитель став одним 3 найважливіших, якщо не найважливішим фактором шкільного життя [Mедынский 1917:16-35].

Якщо в кількісному відношенні викладацькі кадри початкових шкіл Харківського губернії в більшості відповідали вимогам часу i щорічно збільшувалися приблизно на 200 осіб, то якісний стан, тобто рівень освіти, був далеко не найкращим. Так, у 1910 році із 3381 викладачів, які працювали в усіх освітянських початкових школах губернії, лише $10 \%$ отримали спеціальну педагогічну освіту у вчительських інститутах, семінаріях і школах або вищих навчальних закладах. Ще у 37 \% викладачів за плечима були звичайні гімназії або реальні училища, в яких передбачалося вивчення основ педагогічної діяльності [Абрамов1998: 44-55]. Решта викладацького складу харківських народних шкіл в цей час мала лише початкову освіту або зовсім не мала ніякої систематизованої освіти. Таке становище 3 недопустимо низьким рівнем спеціально-педагогічної освіти народних вчителів викликало клопотання з боку органів земського самоврядування, губернської адміністрації, управління Харківського учбового округу та й у цілому всієї передової громадськості Харківщини, які оцінювали завдання підготовки народних вчителів як одне 3 найбільш важливих соціальних завдань [Ворошилова 1996: 75-77].

Передові земські діячі взяли в свої руки ініціативу створення в Харківській губернії загального методичного центру з підготовки шкільних учителів. В основу земської практики підготовки шкільних учителів Харківським земством були покладені рекомендації К. Д. Ушинського, який підкреслював принципову важливість для вчителя народної школи не тільки вміти викладати, але й мати відповідний характер, моральність, переконання, оскільки на вихованців таких шкіл більшою мірою, ніж наука, що тут викладалася, впливала особи- 
стість учителя. У практиці земських учительських семінарій особливо цінувалися такі якості майбутнього шкільного вчителя, як любов до своєї професії, розуміння іiї суспільної значимості, працьовитість, уміння логічно мислити, готовність стоїчно переборювати життєві труднощі [Положение учителя 1898: 9-12]. На початку ХХ ст. харківські земці почали інтенсивно розробляти i виносити на обговорення всілякі плани відродження великого загально губернського педагогічно-методичного центру, такого, яким вже був у свій час (1811-1858) Харківський педагогічний інститут при Харківському університеті. Такі плани дістали широкий суспільний резонанс й лягли в основу діяльності як земства, так і державних органів влади [Доклады Харьковской управы 1915:261].

Харківське земство відводило велику роль у підготовці шкільних учителів щорічним літнім короткочасним (до двох місяців) педагогічним курсам. Так, на черговій сесії губернських земських зборів 10 грудня 1911 р. була прийнята програма дворічних літніх курсів для вчителів, а на надзвичайній сесії 30 червня 1012 р. був схвалений і направлений на затвердження в Міністерство народної освіти учбовий план і статут цих курсів [Пирумова 1993:119-126]. До навчального плану першого року навчання (1-й цикл) були включені такі предмети як: педагогічна психологія (16 годин), методика викладання російської мови (12 годин), математики (14 годин), природознавство (6 годин), малювання і ручна праця (12 годин), а також народна і дитяча література (10 годин). На другому році навчання (2-й цикл програми) вивчались: психологія дитинства (16 годин), російська історія (22 годин), російська література (16 годин), українська історія і література (16 годин), вчення про право і державу (14 годин), питання народного господарства та вітчизнознавство (10 годин) [Звягинцев а 1914: 359-369].

Завдяки земській ініціативі на Харківщині, починаючи з 1909 р., кожне літо для земських вчителів почали проводити короткочасні педагогічні курси. При цьому, якщо в 1909 р. на земських педагогічних курсах пройшли навчання тільки 21 вчитель, то у 1910 р. таких учителів було 499, а в 1911 р.
- вже 570 із 3626 земських вчителів усієї Харківської губернії [Звягинцев б 1915:3841]. На курсах 1911 р. найбільше було представників Харківського повіту (109 чоловік), потім йшли Вовчанський (56 чоловік), Старобільський (47 чоловік) і Сумський (34 чоловік) повіти. Від самого Харкова було представлено 48 курсистів [Доклады Харьковской управы 1915:253-259]. Основні видатки по організації цих курсів несли губернська і повітові управи. Так, у 1911 р. за рахунок губернського земства пройшли підготовку 83 вчителі та 217 вчительок, за рахунок повітових земств - відповідно 11 і 25, а за рахунок різних приватних установ i власний рахунок самих вчителів навчалось 159 чоловік, тобто менше третини від загального числа курсистів. У 1913 році земства виділили на добру справу 19,9 тис. крб, а в 1914 р. - 21,5 тис. крб, зокрема, курсистам, що були направлені від повітових земств, оплачувалося проживання в гуртожитку і щоденно видавалося по 1 крб. на харчування [Доклады Харьковской губернской 1913:80-87].

Робота земських педагогічних курсів звичайно починалася в травні і тривала 3537 днів. Заняття проходили в просторих приміщеннях так званого Народного будинку, який належав Товариству освіти і був розташований на колишній Кінній площі (цей будинок був розібраний в 1930 році). Проживали курсисти майже поряд: чоловіки - в казармах Воронізького піхотного полку, а жінки - у приміщенні міського ремісничого училища. Заможні слухачі курсів жили власним коштом на приватних квартирах. Триразове харчування було організовано в їдальні Народного будинку. Губернська управа також забезпечувала курсистам пільговий проїзд на громадському транспорті - міській конці, що належала Акціонерному бельгійському товариству, та електричних трамваях, що належали міському правлінню [Вологдин 1914: 399-411].

Основний навчальний процес на земських педагогічних курсах складався з теоретичних лекцій, практичних занять і педагогічної практики, лекції читали такі відомі в губернії досвідчені педагоги-методисти як: С. Г. Попич (педагогічна психологія), В. О. Флєров (методика російської мови), 
С. I. Шохор-Троцький (методика математики), М. І. Сухопаров (методика фізики), П. Л. Мальчевський (методика хімії), професор В. М. Арнольді (методика ботаніки), O. М. Нікольський (методика зоології), В. В. Фавр (шкільна гігієна) та професор O. I. Набоких (природа Харківщини). Усі вони $з$ дозволу губернатора і попечителя учбового округу працювали на курсах по договору із земською управою і одержували від неї відповідні грошові винагороди [Цифровые данные к обзору 1917: 388]. За свідченням керівника земських педкурсів 1914 р. приват-доцента Харківського університету О.М.Покровського, щоденно для курсистів проводилося по чотири-п'ять лекцій, а всього було прочитано 156 лекцій, крім консультацій, які призначалися на вечір [Веселовский 1914: 391-398].

Теоретичні знання з методики викладання окремих учбових програм курсисти закріплювали на педагогічній практиці, що проходила в спеціальній початковій школі, створеній при курсах. Після основних занять, починаючи 319 годин, курсисти брали участь в роботі декількох учбово-методичних комісій (гуртків по інтересам). Декілька днів роботи курсів повністю були присвячені учбовим екскурсіям в різні музеї, бібліотеки, виставки Харкова [Обухов 1912: 1622-1627]. Так, наприклад, в 1914 р. курсисти під керівництвом М. К. Кнічера ознайомилися з експозиціями Зоологічного музею і Музею витончених мистецтв, відвідали Ботанічний та Бактеріологічний інституту, Анатомічний театр жіночого медінституту, Харківську громадську бібліотеку та бібліотеку-читальню Товариства освіти [Пирумова 1986: 45-63]. У вихідні дні, які були тільки у свята, для курсистів влаштовували в Народному будинку безкоштовні виставки і концерти. Так, наприклад, у 1914 р. закриттю курсів була присвячена виставка української трупи по п’єсі Б. Грінченка «Степовий гість». Провідну роль в організації подібних вистав і концертів зіграв колишній голова правління Товариства освіти і комісії з управління Народним будинком С. О. Раєвський [Доклады Харьковской губернской 1913:88-92].

Харківське земство намагалося мобілізувати суспільні сили на пошуки най- більш раціональних шляхів та форм відродження в регіоні такого центру учбовометодичної підготовки вчителів, яким тут був в свій час педагогічний інститут. Ці пошуки не відразу охопили всі напрямки i спочатку теж звелись до організації короткочасних педагогічних курсів. Такі курси почали досить стабільно працювати після прийняття урядом 5 травня 1875 р. «Правил про тимчасові педагогічні курси». Від початкового завдання короткочасного інструктування вчителів народних шкіл засновники курсів поступово перейшли до різноманітних форм більш тривалого і поглибленого їх навчання, ініціатором суттєвого пожвавлення роботи так званих окружних педагогічних курсів i ïx якісного перетворення в умовах підйому суспільнопедагогічного руху в губернії на початку XX ст. став попечитель Харківського учбового округу П. Є. Соколовський. Курс навчання був шеститижневий і звичайно розпочинався 8 червня.

Окрім теоретичних занять, які проходили в приміщенні Харківського університету навчальний план передбачав також i практичні заняття. Щоденна тривалість занять доходила до 8-9 годин: 39 до 14 години проходили практичні заняття, а 317 до 20, або навіть до 21 години, - теоретичні [Белоконский 1908: 8-12].

Особливе значення надавалось педагогічній практиці курсистів, для чого на куpсах було створено спеціальну навчальну школу з чотирма відділеннями. Слухачі курсів на протязі першого тижня відвідували уроки в цій школі, які проводили директор школи М. П. Дашевський та деякі викладачі курсів, після ознайомлення 3 кращими методами і прийомами викладання курсисти протягом п'яти тижнів самостійно проводили уроки з різних предметів під керівництво досвідчених методистів [Труды Харьковского губернского 1915: 195]. При цьому велику увагу приділяли підготовці до уроків, план їх проведення розглядався i затверджувався методистами, підсумки проведеного уроку піддавалися детальному аналізу на особливих педагогічних зборах при участі всіх присутніх на цьому уроці. Така організація професійної підготовки курсистів дозволила озброювати їх хоро- 
шою педагогічною технікою для роботи в школі. Але навчання на курсах не передбачало спеціалізації з предметів або хоч би по циклах гуманітарних і точних наук [Ворошилова 1996: 71-77].

Хоча окружні педагогічні курси існували в Харківській губернії ще 3 70-х років XIX ст., але найбільша активність в їх діяльності спостерігались в 1910-1914 роки, коли поруч з міністерськими засобами вони почали одержувати серйозну матеріальну підтримку збоку Харківського земства. Щорічно губернська і повітові управи направляли на окружні курси за свій рахунок від 97 до 100 народних вчителів, крім цього на оплату викладачам, що викладали на курсах, земство виділяло до 3 тис. крб. на рік. Всього за 1910-1914 рр. окружні педагогічні курси закінчило близько 1,3 тис. вчителів, а земські курси - до 2 тис. вчителів, таким чином, за 5 років на педагогічних курсах було навчено близько 3,3 тис. вчителів, що становило майже $100 \%$ від числа всіх вчителів, які в той час працювали в народних училищах Харківськоїгубернії. Завдяки такій масовості і високій якості отриманих знань, випускники цих курсів надали немалу послугу справі розвитку початкової народної освіти на Харківщині [Абрамов 1998: 44-60].

Створені в Харківській губернії спочатку лише як засіб підвищення рівня освіти та методичної кваліфікації вчителів початкових шкіл, земські й окружні педагогічні курси невдовзі набули значно більшої ваги. В 1910-1914 рр. на новому етапі урядової політики в області педагогічної освіти вони стали однією 3 основних форм об'єднаної державної, земської та громадської участі в розвитку народної освіти, серйозним фактором не лише професіонального та культурного росту земських вчителів, але й якісного перетворення всієї шкільної справи. Саме це значення та масовість педагогічних курсів, широка участь в їх роботі передових представників суспільства визначило появу різних проектів та планів по створенню на базі тимчасових педагогічних курсів постійно діючого загально-губернського навчального закладу - Харківського педагогічного інституту.
Із такою ініціативою одним $з$ перших виступив попечитель учбового округу П. Є. Соколовський, який 30 жовтня 1913 р. відіслав в губернську земську управу офіційну пропозицію розглянути на сумісному засіданні питання про перетворення педагогічних курсів в педагогічний інститут [Народное образование в земствах 1914: 7985]. Нарада відбулася через два тижні у приміщенні губернської земської управи. У ній взяли участь всі зацікавлені сторони: голова управи В. В. Акігиєв, члени управи Р. С. Будберг, О. С. Беніке, О. І. Глушков, В. П. Плегуеєв, голова шкільної комісії С. О. Літарєв та попечитель учбового округу П. С. Соколовський [Белоконский 1908: 1-13]. Земські діячі з цікавістю вислухали доповідь П. Є. Соколовського «Про установи в губернії земського педагогічного інституту» і прийняли активу участь в його обговоренні. При підведенні підсумків учасники наради одностайно проголосували за запропонований проект відродження в губернії педагогічного інституту, але тепер він повинен був існувати не при університеті, як це було в 1811-1850 pр., а при губернському земстві [Чехов 1912: 52-80]. На нараді під час дискусії був розроблений i прийнятий статут інституту, а також визначені основні джерела його фінансування, до яких насамперед, були віднесені щорічні обов'язкові відрахування губернського земства, субсидії від Міністерства народної освіти, плата за навчання вільних слухачів, доходи від публічних лекцій, концертів, спектаклів, які мав право влаштовувати інститут, доходи від його друкованих видань i, нарешті, різні пожертви.

За основу статуту нового навчального закладу, який було названо «Педагогічний інститут харківського губернського земства», було взято допрацьований статут земських педагогічних курсів, що був прийнятий на сесії губернських земських зборів ще в червні 1917 p.

Згідно 3 прийнятим земцями статутом, інститут належав до відання міністерства народної освіти і підпорядковувався безпосередньо попечителю навчального округу. Його головним завданням було «надавати спеціально-педагогічну освіту особами обох статей». Курс навчання три- 
вав два роки, протягом яких слухачі повинні були серйозно вивчати такі предмети, як фізику, хімію, математику, ботаніку, зоологію, анатомію, фізіологію, шкільну гігієну, землезнавство, батьківщинознавство, історію, літератури, богослів'я, психологію, історію педагогіки, педагогіку, школознавство, дидактику, логіку, малювання і креслення, ручну працю, співи, рухливі ігри та гімнастику, а також методику викладання різних шкільних предметів.Педагогічну практику передбачалось проходити в однокласній і двокласній початкових школах, які входили до структури інституту. Після закінчення інституту слухачі складали іспити й одержували учительські свідоцтва [Слобожанин 1913:382-384].

Здійснення проекту по створенню губернського педагогічного інституту цілком дозволяло його розробникам розраховувати на певне вирішення в Харківській губернії проблем 3 педагогічними кадрами як для початкових, так і для середніх навчальних закладів.Процес реалізації цього проекту булорозпочато вже в кінці 1913 - на початку 1914 року. Саме в цей період була сформована попечительська рада інституту, яку очолив голова губернської управи В. В. Акішев [Материалы к вопросу об участи 1916: 126-148]. До іiі компетенції увійшли всі фінансові та господарські питання, пов'язаніз формуванням інституту i, насамперед, питання про набір штатувикладачів та співробітників інституту та пошук коштів для їх утримання.Одним 3 найскладнішим завданням було придбання чи будівництво власного приміщення в Харкові, на що вимагалось не менше 300 тис. крб.

Фінансові проблеми i труднощі, які ще більше посилили 3 початком першої світової війни, не дозволили завершити процес створення педагогічного інституту за той строк, на який розраховували його засновники, тобто до початку 1915 року [Труды Харьковского губернского 1915: 195]. Призначення в цей час міністерством на посаду попечителя Харківського навчального округу відставного генерала О. Л. Королькова замість П. С. Соколовського залишило справу створення педінституту без його основного натхненника.
У пореформеній Харківській губернії в діяльності земства, поряд з розвитком народноїосвіти, важливе місце займали питання культурно-просвітньої роботи серед сільського населення. Різні форми позашкільної освіти розглядалися земською педагогічною громадськістю і як засіб зміцнення зв'язок загальноосвітньої школи 3 життям, усунення протиріч між педагогами i батьками школярів, і як засіб подолання рецидивів неграмотності, і як засіб підвищення загальної культури українського села. Розвиваючи в селі найпростіші форми позашкільної роботи, такі, наприклад, як народні читання, земство сприяло пробудженню інтересу селян до поліпшення свого господарства, до питань гігієни і санітаpiï, до морально-етичних i релігійних проблема [Пругавин 1916:412-418].

Усі форми земської позашкільної просвітньої роботи були тісно пов'язані між собою й разом 3 тим строго диференційовані з урахуванням різних категорій сільського населення. Так, для сільської молоді поряд 3 додатковими заняттями по загальноосвітніх предметах пропонувалися професійні курси сільськогосподарського і ремісничого профілю. На сільську молодь були розраховані бібліотеки i читальні. Людям старшого віку, що були неграмотними, призначалися різного роду бесіди, які проводилися земськими вчителями, лікарями, агрономами, а також читання науковопопулярної літератури, що часто супроводжувалися показом діапозитивів [Цирульников 1996: 15-23].

Висновки і перспективи подальших досліджень. За час своєї більш ніж піввікової діяльності земське самоврядування проробило величезну роботу з розвитку продуктивних сил України.

Оглядаючи історичний досвід діяльність земських установ Харківської губерніï, необхідно віддати належне земствам за те, що їх дії в сфері народної освіти в основному відповідали вимогам тогочасного українського суспільства. Незважаючи на всі труднощі та перешкоди, що виникали на шляху Харківського земства у процесі вирішення ним проблем народної освіти, його діяльність привела до значних зрушень на краще. Земство виступило головним прові- 
дником культури і освіти в народні маси, створило власну ефективну для свого часу систему підготовки вчительських кадрів для початкової народної школи. Земська діяльність активно сприяла розвитку духовної культури народних мас, вихованню поваги до науки і духовних благ, демократизації знання.

Введення земського самоврядування в українських губерніях значно розширило можливості соціальної творчості в сфері освіти і культури, відкрило шляхи сміливого педагогічного експериментаторства. Земська діяльність заклала в Україні міцні основи світської освіти народних мас, виховала в народі повагу до школи, пізнавальний інтерес до наукового знання. Українське земське вчительство дорадянської епохи являло собою самий численний загін вітчизняної інтелігенції. Її формування йшло протягом п'яти післяреформених десятиліть і значною мірою було пов'язане 3 ініціативною роботою земського самоврядування як в галузі шкільного будівництва, так й в галузі позашкільної просвітницької роботи.

Земський учитель став засновником i творцем народної школи, він був центром, на якому грунтувалися успіхи народної школи. Практична значимість дослідження складається в можливості використання в сучасних умовах окремих елементів досвіду земських установ для рішення фінансових, кадрових, змістовних та інших проблем народної освіти на регіональному тазагальноукраїнському рівнях. Вироблений автором новий погляд на земську діяльність в галузі шкільного будівництва й забезпечення початкової народної школи вчительськими кадрами повинен знайти відбиття при відновленні змісту освіти в українських педагогічних вишах $\mathrm{i}$ коледжах.

\section{ЛITEPATУРA}

1. Абрамов В.Ф. Земство, народное образование и просвещение: История развития земской народной школь во второй половине XIX- начале ХХ в. в России // Вопросы истории. 1998. № 8. C. $44-60$.

2. БелоконскийИ.П. Оживление деятельности земства в сфере народного образования // Русская школа. 1908. № 12. С. 1-13.

3. Веселовский Б. Б. Всеобщее обучение и земство // Юбилейный земский сборник (1864-1914). СПб.: Изд-во т-ва Поповой, 1914. С. 391-398.

4. Вологдин Б. П. Земская статистика народного образования // Юбилейный земский сборник (1864-1914). СПб., 1914. С. 399-411.

5. Ворошилова С. В. Деятельность земств в сфере народного образования // Вопросы крестьяноведения. Саратов, 1996. Bыn. 3. С. 71-77.

6. Гавриш Р. Л. Шкільна діяльність земського самоврядування на Лівобережній Україні в 1865-1919 роках: Автореф. дис... канд. іст. наук: 07.00.01. X., 1999. 19 c.

7. Гордеенко Е. С. О положении сельского хозяйства и земства в Харьковской губернии. Х.: Тип. губ. правления, $1885.65 \mathrm{c}$.

8. ГузА.М. Культурно-освітня діяльність земських установ в Україні (1864-1914 рр.): Автореф. дис... канд. іст. наук: 07.00.01. К., 1997. 24 c.

9. Доклады Харьковской губернской земской управы 1914 года. Х.: Тип. губ. правления, 1915. 369 c.

10. Доклады Харьковской губернской земской управы губернскому собранию очередной сессии 1912 года по народному образованию. Х.: Тип. губ. правления, 1913. - $118 c$.

11. ДровозюкЛ.М. Земська школа в Україні // Рідна школа. 1997. № 12. С. 73-74.

12. Ежегодник МВД. Год шестой 1912. СПб.: Тип. МВД, 1913. $717 \mathrm{c}$.

13. Звягинцев Е. А. Земство и учебное ведомство // Юбилейный земский сборник (1864-1914). СПб., Tun. В. Кирибаума,1914. С. 359-369.

14. Звягинцев Е. А. Полвека земской деятельности по народному образованию. М.: Задруга, 1915. 96 с.

15. Звягиниев Е.А., Обухов А.М., Серополко С.О., Чехов Н.В. Народное образование в земствах. М.: Задруга, 1914. 443 c.

16. Земская школа и педагогика: Материаль науч. семинара «Земская школа и педагогика». Белгород: БелГУ, 1997. 201 с.

17. Земско-школьная деятельность в Харьковской губернии. Х.: Тип. губ. правл., 1912. С. 129-282.

18. Земство и народное образование // Русская школа. 1909. № 10. С. 17.

19. Корж Л. В. Освітня діяльність земств Харківської губернії (в кінџі XIX - на початку XX cm.): Автореф. дис... канд. пед. наук: 13.00.01. K., 1999. 19 c.

20. Корф Н. А. Земский вопрос (о народном образовании). СПб., 1867. 64 с.

21. Курченко В. В. Діяльність земств Украӥни у розвитку освіти (1864-1914 рр.): Автореф. дис... канд. іст. наук: 07.00.01. Х., 1998. 19 c.

22. Мармазова О.І. Просвітнииька діяльність земств в Україні (кінець XIX - початок XX cm.): Автореф. дис... канд. іст. наук: 07.00.01. Донецьк, 1998. $16 \mathrm{c}$.

23. Материаль к вопросу об участии Харьковского губернского земства в развитии начального на- 
родного образования // Материальл по статистике Харьковской губернии. Х.: Тип. М. Зильберга, 1916. С. 126-148.

24. Медынский Е. Бюджеты земских школ // Земское дело. 1917. № 18. С.16-35.

25. Народное образование // Веселовский Б.Б. История земства за сорок лет. СПб.: Изд-во О. Н. Поповой, 1909. С. 447-592.

26. Народное образование в земствах. Основы организации и практика дела: Сб. под ред. Е. А. Звягинцева. М.: Задруга, 1914. - 445 с.

27. Обухов А. Земство и средняя школа // Земское дело. 1912. № 24. С. 1622-1627.

28. Отчет об устройстве земских школ в Харьковской губернии. Х.: Тип. Зильберга, 1912. 169 с.

29. Пирумова Н. М. Земства и просвещение // Российская педагогическая энциклопедия. М., 1993. T.1. C. 329.

30. Положение учителя земской школь // Журнал Министерства народного просвещения. 1898. 4. 190. C. 9-12.

31. Процесс образования земской интеллигенции (конеи 60-х - 80-е годы ХІХ в.) // Пирумова Н. М. Земская интеллигенция и ее роль в общественной борьбе до начала ХХ в. М.: Наука, 1986. С. 45-63.

32. ПругавинА.С. Запросы народа и обязанности земств в области просвещения. СПб.: Тип. МВД, 1916. $547 \mathrm{c}$.

33. Слобожанин М. Из истории и опыта земских учреждений в России. СПб., 1913. 551 c.
34. Соколов М. Общеземский съезд по народному образованию и земская практика // Земское дело. 1912. № 13-14. С. 838-843.

35. Статистический ежегодник Харьковской губернской управы. Харьков: Тип. Печат. дело, 1908. $244 c$.

36. Статистическое обозрение Российской империи. СПб.: Деп. ген. штаба, 1901. 683 с.

37. Труды Харьковского губ. стат. комитета. Х.: Tun. yн-ma, 1915. Bbin. 16. 195 c.

38. Цирульников А. Земское образование: история и современные уроки // Новые иенности образования: образование и сообщество. М., 1996. Bыn.5. C. 15-23.

39. Цифровые данные к обзору Харьковской губернии. Х.: Тип. Печат. дело, 1917. 388 c.

40. Чарнолуский В.И. Вопросы народного образования на первом общеземском съезде // Русская школа. 1911. № 12. С. 87-116.

41. Чарнолуский В.И. Земство и народное образование: Очерки из прошлого и настоящего земской деятельности в различных отраслях обществественного образования. Формы, типь, результаты и очередные задачи земского хозяйства и земских учреждений в этой области. СПб., 1910. Ч. 1. $186 \mathrm{c.}$

42. Чехов Н. В. Земская школа до 1905 года // Народное образование в Росии с 60-х годов XIX века. M., 1912. C. 52-80.

\section{REFERENCES}

1. Abramov VF Zemstvo, public education and enlightenment: The history of the development of the Zemstvo public school in the second half of the XIX - early XX century. in Russia // Questions of history. 1998. № 8. P. 44-60 [in Russian].

2. БелоконскийИП Revival of zemstvo activity in the sphere of public education // Russian school. 1908. № 12. pp. 1-13 [in Russian].

3. Veselovsky BB General education and zemstvo // Jubilee zemstvo collection (1864-1914). SPb.: Izd-vo tva Popovoi, 1914. S. 391-398[in Russian].

4. Vologdin BP Zemsky statistics of public education // Jubilee Zemsky collection (1864-1914). SPb., 1914. S. 399-411[in Russian].

5. Voroshilova SV Activities of zemstvos in the field of public education // Questions of peasant studies. Saratov, 1996. Issue. 3. P. 71-77[in Russian].

6. ГавришР.Л. School activity of zemstvo selfgovernment in the Left Bank of Ukraine in 18651919: Author's abstract. Candidate of Dissertation ist. Science: 07.00.01. H., 1999. 19 p. [in Russian]

7. Gordeenko ES On the situation of agriculture and zemstvos in the Kharkiv province. H.: Type. gub. Board, 1885.65 p. [in Russian]

8. ГузА.M. Cultural and educational activities of zemstvo institutions in Ukraine (1864-1914): Abstract. Candidate of Dissertation ist. Science: 07.00.01. K., 1997. 24 p. [in Russian]

9. Reports of the Kharkiv provincial zemstvo administration of 1914. H.: Type. gub. Board, 1915. 369 p. [in Russian]

10. Reports of the Kharkiv Provincial Zemstvo to the Provincial Assembly of the regular session of 1912 on public education. H.: Type. gub. Board, 1913. 118p. [in Russian]

11. ДровозюкЛ.M. Zemsky school in Ukraine // Native school. 1997. № 12. pp. 73-74[in Russian].

12. Yearbook of the Ministry of Internal Affairs. Year six 1912. SPb.: Type. MVD, 1913. 717 p.

13. Zvyagintsev EA Zemstvo and educational department // Jubilee Zemstvo collection (1864-1914). SPb., Tip. W. Kirschbaum, 1914. P. 359-369[in Russian].

14. Zvyagintsev EA Half a century of zemstvo activity in public education. M.: Zadruga, 1915. 96 p. [in Russian]

15. Zvyagintsev EA, Obukhov AM, Seropolko SO, Chekhov NV Public education in zemstvos. M.: Zadruga, 1914. 443 s. [in Russian]

16. Zemskaya school and pedagogy: Materials of science. seminar "Zemskaya school and pedagogy». Belgorod: BelGU, 1997. 201 p. [in Russian]

17. Zemsko-school activities in the Kharkiv province. Kh.: Tip. gub. Board, 1912. P. 129-282[in Russian].

18. Zemstvo and public education // Russian school. 1909. № 10. P. 17[in Russian].

19. Korzh LV Educational activity of zemstvos of the Kharkiv province (in the end of XIX - in the beginning of the XX century): Author's abstract. Candidate of Pedagogical Sciences Science: 13.00.01. K., 1999. 19 p. [in Russian]

20. Korf NA Zemsky question (about public education). SPb., 1867. 64 p. [in Russian] 
21. Kurchenko VV Activity of zemstvos of Ukraine in development of education (1864-1914): Author's abstract. Candidate of Dissertation ist. Science: 07.00.01. H., 1998. 19 p. [in Russian]

22. МармазоваO.I. Educational activity of zemstvos in Ukraine (end of XIX - beginning of XX century): Author's abstract. Candidate of Dissertation ist. Science: 07.00.01. Donetsk, 1998. 16 p. [in Russian]

23. Materials on the question of the participation of the Kharkiv provincial zemstvo in the development of primary education // Materials on the statistics of the Kharkiv province. delo. 1917. № 18. P.16-35[in Russian].

25. Public education // Veselovsky BB History of the zemstvo for forty years. SPb.: Izd-vo ON Popova, 1909. S. 447-592[in Russian].

26. Public education in zemstvos. Fundamentals of organization and practice: Sat. under ed. EA Zvyagintseva. M.: Zadruga, 1914. 445 s. [in Russian]

27. Obukhov A. Zemstvo and secondary school // Zemskoe delo. 1912. № 24. S. 1622-1627[in Russian].

28. Report on the organization of zemstvo schools in the Kharkiv province. - H : Tip. Zilberg, 1912. 169 . [in Russian]

29. Pirumova N.M. Zemstvos and enlightenment // Russian [in Russian]pedagogical encyclopedia. M., 1993. Vol.1. S. 329 [in Russian].

30. The position of the teacher of the Zemsky school // Journal of the Ministry of Public Education. 1898. Ch. 190. S. 9-12[in Russian].

31. The process of formation of the Zemsky intelligentsia (late 60's - 80's of the XIX century.) // Pirumova NM Zemsky intelligentsia and its role in the social struggle until the beginning of the XX century. M.: Nauka, 1986. P. 45-63[in Russian].

32. ПругавинA.C. Inquiries of the people and responsibilities of zemstvos in the field of education. SPb.: Tip. MVD, 1916. 547 p.

33. Slobozhanin M. From the history and experience of zemstvo institutions in Russia. SPb., 1913. 551 p. [in Russian]

34. Sokolov M. All-Land Congress on Public Education and Zemsky Practice // Zemsky Delo. 1912. № 1314. P. 838-843[in Russian].

35. Statistical Yearbook of the Kharkiv Provincial Administration. Kharkiv: Type. Printing. case, 1908. 244 p. [in Russian]

36. Statistical Review of the Russian Empire. SPb.: Dep.gen.shtaba, 1901. $683 \mathrm{~s}$.

37. Proceedings of the Kharkiv Provincial Statistical Committee. H.: Type. University, 1915. Issue. 16. 195 p. [in Russian]

38. Tsirulnikov A. Zemsky education: history and modern lessons // New values of education: education and community. M., 1996. Vyp. 5. P. 15-23 [in Russian].

39. Numerical data for the survey of the Kharkiv province. Kh .: Tip. Printing. case.1917. 388 p. [in Russian]

40. Чарнолуский В.И. Questions of public education at the first national congress // Russian school. 1911. № 12. P. 87-116[in Russian].

41. Чарнолуский В.И. Zemstvo and public education: Essays on past and present of zemstvo activity in various branches of public education[in Russian]. 